\title{
Unaccusativity and Perfect Auxiliary Selection in Romance: Theory and an Observational Study in Second Language Acquisition
}

\author{
Christopher D. Sams \\ Stephen F. Austin State University \\ Texas, United States \\ E-mail: samsc@sfasu.edu
}

Received: June 8, 2020

Accepted: July 24, 2020

Published: July 28, 2020

doi:10.5296/ijl.v12i4.17445

URL: https://doi.org/10.5296/ijl.v12i4.17445

\begin{abstract}
The aim of this paper is to investigate the properties associated with unaccusativity and the selection of auxiliary verbs (AUX) in the perfect tenses of the modern Romance languages. The modern languages that have a split-AUX system (such as Italian and French) operate under a principle in which some intransitive verbs select the equivalent of to be as their AUX in the compound past tenses, and others select the equivalent of to have. In research I have conducted over the past decade in the Italian language classroom, Bentley and Eythórsson's auxiliary selection hierarchy (ASH) is best suited to explain how L2 Italian learners acquire the ability to make the appropriate surface AUX selection.
\end{abstract}

Keywords: Unaccusativity, Split intransitivity, Romance, Second language acquisition, Morphosyntax, Semantics

Consider the following sentences in Italian and French:

$\begin{array}{clllll}\text { (1a) Piero } & \text { ha } & \text { letto } & \text { il } & \text { libro } & \text { (Italian) } \\ \text { Piero } & \text { has 3.SG.PRES } & \text { to read.PP } & \text { the } & \text { book } & \end{array}$

'Piero read the book'

$\begin{array}{rlc}\text { (1b) Marco } & \text { è } & \text { morto } \\ \text { Marco } & \text { is 3.SG.PRES } & \text { to die.PP }\end{array}$ 
'Marco died'

(1c) Pierre a

Pierre $\mathbf{a}$

has 3.SG.PRES lu

to read.PP le the livre

book

'Pierre read the book'

(1d) Marc

est

mort

Marc is 3.SG.PRES

to die.PP

'Marc died'

In example $(1 \mathrm{a} / \mathrm{c})$, the verbs leggereflire 'to read' has selected the to have AUX, where in $(1 \mathrm{~b} / \mathrm{d})$ the verbs morire/morir 'to die' has selected to be as its AUX. Using the incorrect AUX in the above examples would render the sentence ungrammatical:
$\left(1 a^{\prime}\right) *$ Piero
è
letto
il
libro
(Italian)
Piero
is 3.SG.PRES
to read.PP
the
book
* 'Piero read the book'
(1b')

$\begin{array}{ll}\text { *Marco ha } & \text { morto } \\ \text { Marco has 3.SG.PRES } & \text { to die.PP } \\ \text { * 'Marco died' } & \end{array}$

The same would be true in the alternative AUX were used with the French examples. i.e., *est $l u$ and *a mort.

In part one of this paper, I will present an overview of some of the competing theories that attempt to explain this phenomena in modern Italian and French. In part two, I will present different facets of AUX selection in general, discuss some of the current research, present a brief study, and offer some directions in which to further research in the field.

\section{Introduction and Theoretical Overview}

One of the first attempts at describing this phenomenon comes from the work of Pelrmutter (1978) and his work in Relational Grammar. In this framework, he referred to specific semantic classes of verbs (such as verbs of bodily function) and advanced what is referred to as the Unaccusative Hypothesis. This work was carried on in the GB framework by Burzio (1981, 1986) and Rosen (1981). In the analysis proposed by Perlmutter, there are two subtypes of syntactically different intransitive verbs: unaccusatives and unergatives. Following the discussion in Levin and Rappaport (2005:12), unaccusatives are verbs in which the surface subject is an underlying object, and unergatives are verbs in which the surface subject is an underlying subject. A crucial disagreement here is whether the verb's classification as unaccusative or unegrative is semantically defined, syntactically defined, or a combination of the two. Many of the first attempts in the generative tradition to account for the phenomena were focused on syntactic criteria (Levin and Rappaport Hovav 1995:4). 


\section{Macrothink}

International Journal of Linguistics

ISSN 1948-5425

2020, Vol. 12, No. 4

Following Levin and Rappaport (2005:13) and Perlmutter (1978), we would expect the verbs of bodily function to select the to have AUX, since they are unegrative i.e. the surface subject and underlying subject as the same. Consider the following Italian examples:
(2a) Lorenzo
ha
tossito
Lorenzo
to have 3.SG.PRES
to cough.PP
'Lorenzo coughed'
$\begin{array}{rll}\text { (2b) Giovanni } & \text { ha } & \text { russato } \\ \text { Giovanni } & \text { to have 3.SG.PRES } & \text { to snore.PP }\end{array}$
'Giovanni snored'
(2c) Maria
ha
starunito
Maria
to have 3.SG.PRES
to cough.PP
'Maria sneezed'

This does have a widely cited exception, however, and that is the Italian verb arrossire, 'to blush' which take to be as its AUX (Note 1).
(3a) Il ragazzo
$\grave{\mathbf{e}}$
arrossito
the boy
to be 3.SG.PRES
to blush.PP

'The boy blushed'

This issue is addressed by C. Rosen (1984) in which there are other members of the class of bodily function verbs that cross-linguistically behave as unaccusative verbs as in (3a) above. She suggests that being unaccusative is not completely semantically determined by the verb after all, and observes that there is no single semantic property shared by unaccusative verbs. In her view (and that of several others), unaccusativity is syntactically determined.

McClure (1990) addresses the issue by showing that the semantic classification of the class 'verbs of bodily function' is inadequate from a lexical-semantic perspective. He posits Z. Vendler's Aksionsart classes as criteria for determining unaccusativity and unergativity positing that activity verbs are unegrative and thus take the to have AUX, where achievement verbs are unaccusative and take the to be AUX (Note 2). McClure also makes the observation that these are a class that contains many change-of-state verbs. In this case, McClure's reclassification makes the correct prediction since arrossire can be decomposed lexically as a predicate that means 'to become red', rosso being the adjective in Italian for 'red'. This demonstrated that semantic classification itself should not be done using a priori assumptions, and many times there is a more detailed lexio-semantic generalization possible.

Van Valin and LaPolla (1997) posit lexical decomposition structures with primitive logical operators, and predicates are further divided into classes of states and activities, and then 
allow for variables in argument structure. Van Valin argues that the to be AUX is selected in Italian when the argument is the subject of a state predicate:

andare 'go': [do'(x) CAUSE [BECOME be-at' (x,y)] (Note 3)

An important point regarding AUX selection that doesn't appear to be explicitly treated in these theories is that the verb must be intransitive and unaccusative in order to select for the to be AUX (Note 4).

(4a) Sono

to be.1.SG.PRES

'I went up'

$$
\text { salito }
$$

(Italian)

$$
\text { to go up.PP }
$$

(4b) Ho

to have.3.SG.PRES salito

to go up.PP le

the.F.PL scale.

steps.F.PL

'I went up the steps'

The addition of an overt direct object (le scale in (4b)) requires the use to the to have AUX.

Another approach following Mackenzie 2006 is what he refers to as the Ergative Hypothesis. His analysis deals not only with AUX selection, but with identifying unaccusative i.e. ergative verbs in the Romance languages.

A number of intransitive verbs, particularly indicating movement or change in state and those that have a presentational type meaning, are associated with a cluster of properties across the Romance languages ... Mackenzie (2006:1)

He goes on to mention five of these properties:

1. They select the to be AUX and which also triggers agreement of the subject and past participle.

2. They are compatible with absolute past participle constructions

3. They are compatible with overt expletives in subject position

4. They are compatible with partitive cliticization from the subject (in languages which allow it)

5. They are compatible with postverbal bare subject (in languages which allow them)

These properties are simply another way of classification in trying to determine the relevant facets of the lexio-semantics interface that are involved in AUX selection. It is important to mention that not all languages have each of the properties available i.e., they are independent of the language. There are complications with this analysis, since not all of the properties are available as diagnostics in each language. Furthermore, as Bentley and Eythórsson (2003) observe, other grammatical structures can trigger past participle agreement e.g., pronominal clitics in Italian and Catalan. 
One last analysis I'd like to present is work done by Bentley and Eythórsson (2003). In their analysis, they recognize that not all the Romance languages (or languages in general) operate on the same AUX selection principles. Italian seems to follow many of the theories' principles rigidly, but there appears to be a cline from a rather rigid split intransitive system as in Italian, to one that is less restrictive in regard to the semantic categories that trigger a specific AUX (such as European French), to a language in which the verbs that currently and recently take/took the to be AUX are selecting the to have AUX (Note 5), and finally, languages that used to have a split intransitive system, but now have a to have only past perfect auxiliary e.g., Spanish. Thus we can posit a Romance hierarchy such as the following:

Italian $>$ European French $>$ Canadian French $>$ Spanish

Italian, on one hand, maintains a rather "stable" split-AUX system, where European French operates with a system that is a subset of the Italian system. Canadian French is moving many verbs from the to be AUX to the to have AUX, and finally Spanish is operating with only the to have AUX (Note 6).

Bentley and Eythórsson adopt an auxiliary selection hierarchy (ASH) that ranks the lexical semantic features that are most likely to trigger the to be AUX:

change of location >change of state>continuation of preexisting state (Note 7) > existence of state

Cross-linguistically, the higher a verb is ranked on the hierarchy, the more likely it is to require the to be AUX. They observe that the idea of unaccusativity is on a cline from a core to the periphery (following Sorace 1993b, 2000). In this theory, they consider that this phenomena is morphological i.e., allomorphy. The selection of to have or to be as an AUX is a morphological tense and aspectual marker.

Another point addressed as the well-cited example that telic change can affect the selection. Consider the following in Italian:

(5a) Ho

to have.1.SG.PRES

'I ran' corso (Note 8)

to run.PP

corso

to run.PP a casa

to home

to be.1.SG.PRES

'I ran home'

In (5a), the predicate is atelic and selects for the to have AUX, whereas is (5b) the predicate is telic due to the adjunct to home, which then requires the to be AUX. The relevant point in question is that in this theory it is not only the lexical semantics of the verb that the AUX selection is sensitive to, but the semantics of the predicate. In this case, the lexical semantics of the verb were "overridden" by an adjunct added to the predicate in order to alter the aspect of the verb. 
Bentley and Eythórsson (2003:462) report on a class of Italian verbs (following Maiden and Robustelli [2000:266]) that appear to behave differently in that they have two readings: one of activity and another of telic change-in-state:

A certain number of intransitives take either auxiliary, but the auxiliaries are not freely interchangeable: the selection of avere or essere is usually sensitive to the principles outline above [this is referring and consistent with Bentley and Eythórsson's theory]. With certain verbs, avere is used when the emphasis is on the execution/performance of the activity, especially where the subject can be viewed as actively controlling the activity; essere is used what is in the foreground is a state, change of state or change of position in which the subject undergoes. Among the verbs that behave in this way are: appartenere 'to belong', correre 'to run', circolare 'to circulate, volare 'to fly', saltare 'to jump'...Maiden and Robustelli (2000: 266)

They offer the following example:

(6a) Ha

to have.3.SG.PRES saltato

to jump.PP per

in order to evitare il

avoid the

fosso

'He/she jumped in order to avoid the ditch'

(6b) $\grave{\mathbf{E}}$

saltato

un

bottone

to be. 3.SG.PRES

to jump.PP

a

button

'A button has come off'

There are two competing explanations: the first is that the AUX selection is monitoring for telicity, but this is problematic in that both of the examples that they have offered are in fact, telic (Note 9). The other explanation presented is one of agentivity. The claim here would be that the to have AUX is used for agentivity, while the to be is used in non-agentive contexts (Note 10). Rosen (1984) also claims that the to be AUX is compatible with agentivity (Note 11):

(7a) Ha

to have.3.SG.PRES saltato

to jump.PP sul

on-the letto di

bed of proposito

purpose

'He/she jumped on the bed on purpose'

(7b) $\grave{\mathbf{E}}$ saltata sul letto di proposito

to have.3.SG.PRES to jump.PP.FEM.SING. on-the bed of purpose

'She jumped onto the bed on purpose' (Note 12)

The properties of the ASH can be assigned lexical semantic aspectual properties:

Change of location: (dynamic and telic)

Change in state: (dynamic and telic) 
Continuation of pre-existing state: (no dynamicity, but + stative)

Existence of state: (stative)

Bentley and Eythórsson refer to these properties as [Fn], that is, a feature marked by one of these properties. This also accounts for cross-linguistic variation: that is, French having a more restricted set of verbs that take the to be AUX (Note 13). In this sense, Bentley and Eythórsson can formulate a different rule for Germanic, Romance, or other language families according to how restrictive the split-AUX system is that is operating.

Bentley and Eythórsson formulate a rule as follows (2003:468):

Perfect formation rule in modern Romance

(i) If V(erb) is [+pronominal] (Note 14) > 'be' + past participle

(ii) a. If $\mathrm{P}($ Note 15$)$ (redicate) is marked $[+\mathrm{Fn}]>$ 'be' + past participle

b. elsewhere $>$ 'have' + past participle

Of note here is rule (i) above which correctly predicts the fact that in Italian and French all reflexive verbs take the to be AUX in the past tense. The Romance data suggest that this could be motivated by the fact that to be only takes one semantic argument i.e., is intransitive. When we have a reflexive construction, it is one way of detransitivizing a clause (Note 16):

(8a) Mi

sono

svegliato

(Italian)
1.SG.REFL
to be.1.SG.PRES
to wake up.PP

'I woke up' Lit. 'Myself I work up'

(8b) Je

me suis

réveillé

(French)
1.SG
1.SG.REFL
to be.1.SG.PRES
to wake up.PP

'I woke up' Lit. 'Myself I work up'

On the other hand in German, reflexive verbs take the to have AUX in the present perfect, but again this could be a result of the more restricted system in German AUX-selection.

In summation, this theory predicts and accounts for AUX selection cross-linguistically. It takes into account the lexical semantics of the verb, the effect of delimiting adjuncts on a predicate, and the fact that the probability of taking the to be AUX can vary between languages.

One final treatment comes from Bentley (2006). She brings to center stage the following premise:

Is split-AUX syntactically, semantically, or combinatorially determined?

She argues that most of the treatments have assumed syntactic notions such as "subject" and "object." The accounts that claim that unaccusativity is semantic in nature but has a syntactic component (such as Sorace (2000, 2004) and Levin and Rappaport Hovav [1995]) 
demonstrate the single argument of an unaccusative is analogous syntactically to the object of transitives (Bentley 2006:1).

Regarding the "diagnostics" of spilt intransitivity, Bentley refers to what Alexiadou, Anagnostopoulou, and Everaert (2004) refer to as unaccusativity mismatches. The advocates of the position that purely syntax is responsible for split intransitivity use these mismatches to "invalidate" the position that semantics is the driving force. For example, Rosen (1984: 61-62) claims that in Choctaw the verb 'die' takes a "subject" that appears to be marked for a transitive clause but in Italian the "subject" for an intransitive clause, but the opposite appears to be true of the verb 'sweat' in both languages. This variance suggests to Rosen that "initial grammatical relations cannot be derived from semantic roles." Van Valin (1997) counters this argument "the subject of the Choctaw verb 'die' is only marked as the subject of a transitive clause by case, and, in languages with overt marking of split intransitivity, the case marking of the subject is often insignificant .... as to the semantic role of this argument" (Van Valin (1997: 253). He also posits different semantic factors cross-linguistically that are sensitive to split intransitivity e.g., Aksionsart classes in Italian, but volition in Acehnese. Furthermore, Bentley calls into question (in Italian) whether the system of active morphological alignment vs. accusative morphological alignment plays a significant role in split intransitivity.

\section{Gaps in the Literature and an Observational Study}

\subsection{Clitic-Climbing}

Many of the theories posit that AUX selection is sensitive to mostly semantic criteria, but the notion of clitic climbing is a well-known example that implies that certain syntactic criteria are involved.

Consider the following in Italian:

(9a) Ho

to have.1.SG.PRES

'I had to go there'

(9a') $\mathrm{Ci}$

there dovuto

to have to

dovuto

to have to andar $=\mathrm{ci}$

to $\mathrm{go}=$ there

andare

to go

'I had to go there'

In (9a) the clitic $c i$ is attached to the infinitive andare and the predicate takes the to have AUX as would be predicted. In (9a'), the clitic $c i$ has 'climbed' up to the other position that it can occupy in modern Italian i.e., immediately before the first finite verb form. In this case, the predicate has selected for the to be AUX. If the opposing AUX were used in with construction, it would render the sentence ungrammatical:

(9b)*Ci ho dovuto andare

$\left(9 b^{\prime}\right)^{*}$ Sono dovuto andarci 


\section{Macrothink}

International Journal of Linguistics

ISSN $1948-5425$

2020, Vol. 12, No. 4

Many of the proponents in the GB framework use this as a central tenet of for the claim that syntax, more than semantics (if not completely) determines AUX selection.

\subsection{The Neglect of Thematic Properties}

In line with the theories that posit that semantics has more of an effect on AUX selection, there is quite a bit of literature that is devoted to thematic properties. In Aranovich (2007:11), he reports on this issue as treated in (Sorace 2000) in which Sorace observed "Some [Italian] verbs of change of location, which normally select HAVE, occur with BE if the subject is inanimate. On the other hand, verbs of continuation of state (e.g. durare 'last') go from BE to HAVE when the subject is animate. An example involving the first type (change in location) follows from Sorace (2000):

$\begin{array}{rllllll}\text { (10a) Il pilota } & \text { ha/?è } & \text { atterrato } & \text { sulla } & \text { pista } & \text { di } & \text { emergenza } \\ \text { The pilot } & \text { has/is } & \text { landed } & \text { on-th } & \text { runway } & \text { of } & \text { emergency }\end{array}$

The pilot landed on the emergency runway

$\begin{array}{cccccc}\text { (10b) L'aereo è/?ha } & \text { atterrato } & \text { sulla } & \text { pista } & \text { di } & \text { emergenza } \\ \text { The plane has/is } & \text { landed } & \text { on-the } & \text { runway of } & \text { emergency }\end{array}$

The plane landed on the emergency runway

In (10a), the "subject" 'pilot' is animate, and in (11b), the "subject" 'plane' is inanimate. This is clearly an instance of semantics determining AUX selection, however, though not pointed out in the literature, here it is a case of the semantics of nominals rather than verbal semantics.

\subsection{Dialectology}

There is a considerable amount of work on dialectal variation in Italian (Cennamo 1997), and French (Canale 1978) and Sankoff (1977) that could perhaps yield some interesting observations regarding cross-linguistic typology. One such example comes from Abruzzese, in which the pluperfect calls for both AUX constructions to be used:
(11) So’
'vé
parlate
to be.1SG. PRES
to have.PAST.IMP
spoken

'I had spoken'

(Roberta D'Alessandro and Adam Ledgeway [unpublished])

There are, of course, major complications when dealing with dialectal variation as many sociolinguistic factors can bare upon the data such as bilingualism. 


\section{Macrothink}

\subsection{First and Second Language Acquisition}

Regarding the ASH mentioned earlier, Sorace (1993a, b, 2000) reports that children learning Italian learn the verbs that require the perfective AUX to be, as suggested earlier, from the core to the periphery meaning:

Change of location $>$ change of state $>$ continuation of preexisting state>existence of state

As so far as second language acquisition is concerned, few studies have been done other than Sorace (1993b). There are several interesting facets to investigate here such as if L2 learners are restricted in their use, meaning, how much positive input do they need before understanding the system of AUX selection? Furthermore, is it a system that should be taught implicitly or explicitly?

\subsubsection{Observations in Auxiliary Selection by L1 English Learners of L2 Italian}

In eight Elementary Italian courses I have taught (that contained around 200 students in total), when I teach the passato prossimo (the compound past tense in Italian that requires students to select between the to have (avere) and the to be (essere) AUX), the students are presented with the textbook explanation. It generally lists a number of verbs that take the to be AUX without any linguistic explanation. Many books use an acronym to present the most common verbs that take the to be AUX: Run Ted Save Pam.

Rimanere 'to stay'

Uscire 'to go out'

Nascere 'to be born'

Tornare 'to return'

Essere 'to be'

Diventare 'to become'

Stare 'to stay'

Arrivare 'to arrive'

Venire 'to come'

Entrare 'to enter'

Partire 'to leave'

Andare 'to go'

Morire 'to die'

Along with the selection of the 'to be' AUX, subject past participle agreement is triggered e.g., Sono arrivato 'I arrived' with a masculine subject but Sono arrivata 'I arrived' with a feminine subject (Note 17). Also, all reflexive verbs in Italian (identifiable as they end is -si) take 'to be' as their AUX. On both formal and informal assessments, L2 Italian students have 
a significantly easier time identifying change in location verbs from the ASH as requiring the 'to be' AUX than change of state, continuation of preexisting state, or existence of state. Apart from this, only in the most advanced Italian grammar courses I have taught are students able to monitor for telicity via an adjunct which can manipulate the AUX:

(4a) Sono

salito

(Italian)

to be.1.SG.PRES

to go up.PP

'I went up'

(4b) Ho

salito

le

scale.

to have.3.SG.PRES

to go up.PP

the.F.PL

steps.F.PL

'I went up the steps'

This same phenomenon (split intransitivity) occurs in both French and German, and begs the question how, if at all possible, the system can be explicitly taught.

\subsection{Origin of the Split-AUX System}

In (Vincent 1982), he offers a diachronic explanation into the origin of the AUX system itself, namely, the Latin verbs HABERE 'to have' and ESSE 'to be'. In Classical Latin, the past that existed was that of a simple past tense that relied on verbal morphology:

(12) ROGAVI QUID HABERAT IN ANIMO (Cicero quoted in Vincent [1982:79])

I-asked what he-had in mind

'I asked what he had in mind'

In (12), we have a simple inflected verb form HABERAT meaning 'had.'

Subsequently in Popular Latin, grammaticalization was quite possibly the driving force between the simple past tense becoming a periphrastic construction in which the verbs HABERE 'to have' or ESSE 'to be' were used in conjunction with the past participle to for the synthetic past.
(13) IBI
CASTELLUM
CAESAR
HABUIT
CONSTITUTUM
There
a-camp
Caesar
he-had
built
'Ceasar had built a camp there'
Vincent (1982:84)

In the Popular Latin example in (13), the simple verb meaning 'had' has been replaced with a periphrastic form HABUIT CONSTITUTUM.

Vincent observes that two main tenets the first being that the verb HABERE is transitive where the verb ESSE is intransitive (which could explain some of the semantic ground in which AUX selection is based.) His second observation is that ESSE was used in the passive i.e. a clause that has been detransitivized (Note 18). He also lays the foundation for work in the emergence of the split AUX in the Romance languages as well as the fact that many of 
the languages have lost or are in the synchronic process of neutralizing the split AUX distinction.

In Aranovich (2003), the semantics of AUX selection in Old Spanish are addressed. He does an excellent job of chronicling the innovation and loss of the split AUX system in Old Spanish. He introduces a hypothesis (an alternative to the unaccusative hypothesis) that explains the diachronic development of the Spanish perfect Auxiliary system: The Semantic Displacement Hypothesis which states: "In the diachronic development of the Spanish perfect auxiliary system, the closer the subject is to being a prototypical (Note 19) patient, the longer the predicate resists the displacement of ser by haber." (Note 20) He provides examples from Old Spanish:

- ...aquel omne, que fuera muy bien andante, era llegado [Old Spanish] a tan grand mengua que se sintia dello mucho (LUC).

- 'That man, which had been in good position, had come to be in such need that he was very upset about it.'

- Saladin le dixo quanto avia trabajado por fallar repuesta cierta de la pregunta quel' fiziera (LUC).

- 'Saladin told her how much he had worked in order to find a true answer to the question she posed to him.' Aranovich (2003:2)

He sums up nicely two of the major positions mentioned earlier in this paper:

This analysis supports the semantic approach to split intransitivity defended in Van Valin (1990), Centineo (1986, 1996), Dowty (1991), Zaenen (1993), and Lieber and Baayen (1997). A rival analysis suggests that intransitive verbs were split between those that project their argument as the initial subject of the clause, called unergatives, and those that have an underlying object that is promoted to subject, called unaccusatives. Unaccusatives select the 'be' auxiliaries (Rosen 1984, 1988, Burzio 1986, Perlmutter 1978, 1989, Legendre 1989). One of the arguments for this analysis in Romance is that reflexive verbs also select the "be' auxiliary. I will show that reflexive verbs in Old Spanish are also split into two classes with respect to auxiliary selection, contrary to what the unaccusative analysis would predict. Aranovich (2003:2)

Grammaticalization may be able to account for the rise and decline of Split- AUX systems in the Romance languages. Current data can be used to study the phenomena of the languages (Romance, Germanic, and others) that are leveling the grammatical distinction by moving verbs that are currently in the to be AUX category, and moving them into the to have AUX category. Another question that arises is what is happening to the semantic relationship coded by having a split-AUX system as it slowly disintegrates.

\section{Conclusion}

There is a body of work (Anderson 2006), D. Bentley and Eythórsson (2003), and many others that deal with the cross-linguistic dimension of AUX selection. Some languages that 
have compound systems to express the past are to have only systems (as in Spanish where there is a verb, haber, reserved only for forming the past perfect in contrast to languages that have only one verb to have which is used both for the past formation and other tense uses), some languages with a split-AUX system such as Italian and French (although these language differ in to what extent the system is productive), and finally, languages with a to be only AUX (which are rather common outside of Romance, but Terracinese, a dialect of Italian spoke in Central Italy (Lazio) has such as system.)

In summation, the field surrounding split intransitivity provides many interesting questions for investigation. Is split intransitivity sensitive to syntax, semantics, or both? What exactly gives raise to split intransitive systems, what determines their breakdown, and is there compensatory coding to replace the system? What can be said about cross-linguistic diagnostics for determining unaccusativity? What is the best method for teaching split auxiliary systems to second language learners? And finally, what role does grammaticalization play in the process of languages that develop a system of split intransitivity as well as what are the motivations for the creation of such a system?

\section{References}

Alexiadou, A., Anagnostopoulou, E., \& Everaert, M. (2004). The Unaccusativity Puzzle: Explorations of the Syntax-Lexicon Interface. Oxford: Oxford University Press. https://doi.org/10.1093/acprof:oso/9780199257652.001.0001

Anderson, G. (2006). Auxiliary Verb Constructions. Oxford University Press: London. https://doi.org/10.1093/acprof:oso/9780199280315.001.0001

Aranovich, R. (2003). The Semantics of Auxiliary Selection in Old Spanish. Studies in Language, 27(1), 1-37. https://doi.org/10.1075/s1.27.1.02ara

Aranovich, R. (2007). Split Auxiliary Systems: A Cross-linguistic Perspective. Studies in Language, 69. https://doi.org/10.1075/ts1.69

Bentley, D. (2006). Split Intransitivity in Italian. Mouton de Gruter: Berlin. https://doi.org/10.1515/9783110896053

Bentley, D., \& Eythórsson. (2003). Auxiliary Selection and the Semantics of Unaccusativity. Lingua, 114, 447-471. https://doi.org/10.1016/S0024-3841(03)00068-8

Burzio, L. (1981). Intransitive Verbs and Italian Auxiliaries. Doctoral Dissertation. MIT, Mass.

Burzio, L. (1986). Italian Syntax: A Government and Binding approach. Dordrecht: Reidel. https://doi.org/10.1007/978-94-009-4522-7

Canale, M. (1978). Auxiliaries and Serials between Late Latin and Early Romance. Unpublished Manuscript.

Cennamo, M. (1997). Unaccusativity in some Old Italian Dialects: A Syntacto-semantic Account. Paper presented at the University of Manchester. 
D'Alessandro, R., \& Ledgeway, A. (2003). The Abruzzese T-V System: Feature Spreading and the Double Auxiliary Construction. Unpublished.

Dowty, D. (1979). Word meaning and Montague Grammar. Dordrecht: Reidel. https://doi.org/10.1007/978-94-009-9473-7

Dowty, D. (1991). Thematic Protoroles and Argument Selection. Langage, 67, 547-619. https://doi.org/10.1353/lan.1991.0021

Legendre, G., \& Sorace, A. (2007). Auxiliaries and Intransitivity in French and in Romance. In D. Godard (Ed.), The Romance Languages.

Levin, B., \& Rappaport, M. (1995). Unaccusativity: At the Syntax Semantics Lexical Interface. MIT Press, Cambridge: MA. https://doi.org/10.1017/CBO9780511610479

Levin, B., \& Rappaport, M. (2005). Argument Realization. Cambridge University Press. Cambridge: UK.

Mackenzie, I. (2006). Unaccusative Verbs in Romance Languages. Palgrave Macmillian. London: UK. https://doi.org/10.1057/9780230627550

Maiden, M., \& Robustelli, C. (2000). A Reference Grammar of Modern Italian. NTC Publishing, Chicago.

McClure, W. (1990). A Lexical Semantic Explanation for Unaccusative Mismatches.

Pelrmutter, D. (1978). Impersonal Passives and the Unaccusative Hypothesis. Berkeley Linguistic Society, 4, 126-170. https://doi.org/10.3765/bls.v4i0.2198

Rosch, E. (1978). Principles of Categorization. In E. Rosch, \& B. B. Lloyd (Eds.), Cognition and Categorization, Lawrence Erlbaum Associates (pp. 27-48). Hillsdale.

Rosen, C. (1981). The Relational Structure of Reflexive Clauses: Evidence from Italian. Doctoral Dissertation. Harvard University, Cambridge MA.

Rosen, C. (1984). The Interface between Semantic Roles and Internal Grammar Relations. In D. Perlmutter, \& C. Rosen (Eds.), Studies in Relational Grammar 2 (pp. 38-77). Chicago; IL University of Chicago Press.

Sankoff, D. (1977). L'alternance entre les auxiliairies avoir et être en français parlé à Montréal. Langue Francaise, 34, 81-108. https://doi.org/10.3406/lfr.1977.4818

Sorace, A. (1993a). Incomplete vs. Divergent Representations of Unaccusative Grammars of Italian. Second Language Research, 9, 22-47. https://doi.org/10.1177/026765839300900102

Sorace, A. (1993b). Unaccusativity and the Auxiliary Choice in Non-Native Grammars of Italian and French: Asymmetries and Predictable Indeterminacy. Journal of French Language Studies, 3, 71-93. https://doi.org/10.1017/S0959269500000351

Sorace, A. (2000). Gradience in Auxiliary Selection with Intransitive verbs. Language, 76, 859-890. https://doi.org/10.2307/417202 
Van Valin, R., \& LaPolla, R. (1997). Syntax: Structure, Meaning, and Function. Cambridge University Press. Cambridge: UK. https://doi.org/10.1017/CBO9781139166799

Vendler, Z. (1957). Verbs and Times. Philosophical Review, 56, 143-160. https://doi.org/10.2307/2182371

Vincent, N. (1982). The Development of the Auxiliaries HABERE and ESSE in Romance. In N. Vincent, \& M. Harris (Eds.), Studies in the Romance Verb (pp. 71-96). Croom Helm, London.

\section{Notes}

Note 1. Early work also claimed that volition was the primary feature for which the AUX selection was monitoring. Typologically speaking, volition does seem to play more of a role in AUX selection cross-linguistically.

Note 2. Van Valin and LaPolla (1997) takes a similar approach in RRG.

Note 3. This example also is given in Aranovich (2007:5)

Note 4. Bentley 2006 has dedicated an entire volume to the use of RRG to account for split-intransitivity in Italian.

Note 5. An interesting hypothesis here would be to what extent token frequency preserves a certain verb's movement from the to be AUX to the to have AUX. I addressed the role of frequency in my doctoral dissertation The Effect of frequency on the loss of split intransitivity in Old Spanish (2009).

Note 6. Some languages (though rare in Romance) operate with only the to be AUX.

Note 7. They point out that one exception to this pattern is the verb 'to remain', which consistently selects the to be AUX cross-linguistically.

Note 8. As far as native speakers are concerned, (5a) is ungrammatical. They say "they are waiting for some more information...". The example would be valid if we added the phrase nel parco which would render the translation 'I ran in the part' thus providing the native speakers with context and allowing an activity reading.

Note 9. Native speakers cannot get an iterative reading for (6a), and the example is clearly not an activity. Speakers also will not accept (6b) as grammatical unless the clitic mi is present, indicating something akin to the Spanish Se me cayo...

Note 10. There are many cross-linguistic observations (VanValin (1997) of this type in which both telicity or agentivity are possible "triggers" to change the AUX.

Note 11. I find it counterintuitive that Rosen is primarily arguing for a syntactic treatment of unaccusitivity, yet mentions the fact that agentivity is also a relevant factor in AUX selection. 


\section{Macrothink}

International Journal of Linguistics

ISSN 1948-5425

2020, Vol. 12, No. 4

Note 12. Several native speakers asked for a judgment will not accept (7a) as grammatical in any way. They also report that (7b) can only have the meaning of jumping from the ground to the bed, where (7a) would (if it were grammatical) have to be a female jumping on the bed. This would be consistent with the claim that (7a) would use to have being construed as an activity, where (7b) is a telic event.

Note 13. Optimality Theory has been used to explain cross-linguistic variation since languages seem to be sensitive to different constraints. Legendre (2007) provides a competition based view of the AUX selection process using Optimality Theory.

Note 14. This accounts for the fact that all reflexives verbs take the to be AUX in the past perfect.

Note 15. We need to use P(redicate) here instead of V(erb) since we have seen that the lexical semantics can be altered by the addition of adjuncts.

Note 16. The other evidence is the passive construction which also takes the to be AUX in Popular Latin and the Romance languages.

Note 17. Verbs that take the 'to have' AUX don't trigger agreement, unless there is a pronominal direct object.

Note 18. Many of the modern Romance languages use the to be AUX in the passive construction.

Note 19. This "core to periphery" distinction was mentioned in Bentley and Eythórsson's treatment, and I think that E. Rosch's (1978) prototype theory may be able to play a larger role in AUX selection.

Note 20. See Dowty (1991) for background.

\section{Copyrights}

Copyright for this article is retained by the author(s), with first publication rights granted to the journal.

This is an open-access article distributed under the terms and conditions of the Creative Commons Attribution license (http://creativecommons.org/licenses/by/4.0/) 